\title{
Establishment of the Jean Pictet Fund
}

At its meeting on 12 July 1985 the General Assembly of the Henry Dunant Institute approved the establishment of a «Jean Pictet Fund" and adopted the regulations for it.

The initial capital of the Fund so created came from an anonymous donation of 500,000 Swiss francs to the Henry Dunant Institute as a tribute to Mr. Jean Pictet, Honorary Vice-President of the $I C R C$, former President and former Director of the Henry Dunant Institute.

The annual income from the Fund, minus ten per cent which will be added to the capital, will be used for financing, completely or partially, the Institute's programmes dealing with research, training, teaching, publications and documentation in conformity with the Institute's Statutes.

Priority will be given to training and teaching activities which aim to promote a humanitarian education for every one, though more especially for young people. This type of education can be in the form of courses, seminars, training periods, study visits, meetings, the granting of scholarships, preparing and issuing publications.

$A$ Board of the Fund has been set up to manage the fund and use the income. It is composed of the President of the Institute, its Director and a representative from each of the member institutions (the ICRC, the League, the Swiss Red Cross). Mr. Jean Pictet has consented to be honorary President of the Board.

The donor expressed the wish that other gifts and contributions should be added to the initial capital so that the latter corresponds fully with the Institute's programmes, which are very extensive in their definition. The Assembly at the Institute fully concurs with the donor's wishes.

The International Review has pleasure in announcing the creation of the Jean Pictet Fund. It congratulates the Henry Dunant Institute and Mr. Jean Pictet whose work has thereby received an added mark of esteem. 
The Review adds its sincere gratitude to that expressed by the Institute to the donor for the great generosity displayed. It is convinced that this new Fund will render valuable service in disseminating knowledge of the principles of the Red Cross and humanitarian law and in the training of people devoted to the spirit of the Red Cross-essential elements for the future of the movement and the defence of its ideals.

\title{
Regulations of the Jean Pictet Fund
}

\author{
approved by the General Assembly of the Henry Dunant \\ Institute at its meeting on 12 July 1985
}

\section{Article 1}

The Jean Pictet Fund (hereinafter the Fund) is hereby constituted. The initial capital of the Fund comes from an anonymous donation to the Henry Dunant Institute (hereinafter the Institute) of five hundred thousand Swiss Francs (Fr. 500,000) in tribute to Jean Pictet whose whole life work has been devoted to the Red Cross and Red Crescent Movement. This capital may be increased by donations and bequests.

\section{Article 2}

The aim of the Fund shall be to support the programmes of the Institute in the following areas:

1. research,

2. teaching and training,

3. publications and documentation, in accordance with Article 3 of its Statutes.

Priority shall be given to teaching and training, the aim of which shall be the promotion of humanitarian education for all within the family, at school and in communities, at the local, national and international levels.

This education, open to all but with preference given to youth, shall comprise courses, seminars, training periods, study visits and meetings, the allocation of scholarships and the preparation and publication of works and documents in compliance with the aim set out in para. 1.

Consideration shall also be given to the training of officers and leaders in the spirit of the Red Cross. 


\section{Article 3}

The Board of the Fund shall be composed of the President of the Institute, its Director and a representative of each of the member institutions.

Mr. Jean Pictet shall be honorary president.

\section{Article 4}

The initial capital of the fund shall remain intact. Ten per cent of its annual revenue shall each year be transferred to the capital of the Fund. The Board may use the remaining revenue to finance all or part of the programmes set out in Article 2.

Any unused balance shall accordingly increase the amount available for the following year's allocations, unless the Board decides to pay it into the capital account.

The Board shall ensure appropriate use of the allocations under the projects it has approved. These allocations may in no way be used to cover salaries, travel costs or administrative expenses of the Institute.

\section{Article 5}

Projects and their budgets and the relevant applications for allocations shall as a general rule be submitted to the Board of the Fund by the Institute before 31 December of the year preceding that in which the sums requested shall start to be used. Each project shall comprise a detailed statement proving that it complies with Article 2 of the present regulations.

\section{Article 6}

The Fund shall be administered separately from the other assets of the Institute and shall have its own bookkeeping to be reviewed regularly by auditors. The Fund's annual accounts shall be presented to the General Assembly of the Institute.

\section{Article 7}

The Institute shall be in charge of the administration of the Fund. A sum not exceeding five per cent of the annual revenue from the capital may be used to cover the costs of administrating the Fund. 


\section{Article 8}

The Board shall each year report to the General Assembly of the Institute on the financial position of the Fund, the allocations granted and the progress made with the projects to which the Fund is contributing.

\section{Article 9}

The present regulations may be modified under the same conditions as the Statutes of the Institute. The general aim of the Fund may, however, not be changed.

\section{Article 10}

Should the Institute be dissolved, the institutions which were its members shall continue the administration of the Fund in line with its general aim. They may also entrust its administration to one of them. The Board shall then be composed only of the representatives of these institutions. 